\title{
Agricultural Marketing and Sustainable Development
}

\author{
Jyothi, K.C.* \\ * Research Scholar, DOS in Economics, Kuvempu University, Shankaraghatta - 577 451, Shimoga
}

\begin{abstract}
This paper explains about the Agricultural Marketing and Sustainable Development in Indian economy. This paper introduces the concepts and aims of sustainable agriculture in India. Sustainable agricultural development comprises sustainability of agricultural production and agricultural marketing, sustainability of the rural economy, ecological and environmental sustainability within agricultural systems and sustainability of rural society. India can safely be characterized as an agricultural country despite the recent spurt in manufacturing and services and the declining share of agriculture in the national income, since majority of its workforce (650\%) is still engaged in agriculture and allied activities. It has been the noblest profession in India since the time immemorial and has been carried out on sustainable basis. It is only relatively recent phenomenon that large-scale forest areas, grazing lands and waste lands have been converted into croplands to support the rising population, which has caused ecological imbalance and atmospheric pollution. With no further scope for expansion of agricultural land efforts have been made to enhance the production of food grains using high-yielding variety of seeds, fertilizers and irrigation along with advanced farm equipments. Agriculture is the largest source of employment in India, and food accounts for about half of consumer expenditures. Moving agricultural products from the farm to consumers more efficiently could result in large gains to producers. consumers, and India 's overall economy. More efficient agricultural marketing generates economy wide gains in output and wages, raises agricultural producer prices, reduces consumer food prices, and increases private consumption, particularly by low-income households.

Sustainable agriculture, although a difficult term to define operationally, includes the practice of low input agricultural production technologies. An important condition to adopt these technologies is the access to markets for low input agricultural products. Ability to market these products at profitable prices would provide incentives for farmers to adopt the necessary methods. Contract farming is considered to be an effective means to introduce new production technologies to the farmers by providing assurance on prices and markets for agricultural products. Public extension agencies in developing countries may therefore be concerned to direct their efforts to introduce contract farming models to rural areas, and to encourage private firms to disseminate information on the appropriate production methods. The paper also emphasizes the importance and objectives of agricultural marketing. The conclusion is that to accelerate economic development of the economy, it is necessary to promote sustainability of agricultural marketing.
\end{abstract}

\section{Introduction}

In India Agriculture was practiced formerly on a subsistence basis; the villages were self sufficient, people exchanged their goods, and services within the village on a barter basis. With the development of means of transport and storage facilities, agriculture has become commercial in character; the fanner grows those crops that fetch a better price. Marketing of agricultural produce is considered as an integral part of agriculture, since an agriculturist is encouraged to make more investment and to increase production. Thus there is an increasing awareness that it is not enough to produce a crop or animal product; it must be marketed as well.

Agricultural marketing involves in its simplest form the buying and selling of agricultural produce. This definition of agricultural marketing may be accepted in olden days, when the village economy was more or less self sufficient, when the marketing of agricultural produce presented no difficulty, as the farmer sold his produce directly to the consumer on a cash or barter basis. But, in modem times, marketing of agricultural produce is different from that of olden days. In modem marketing, agricultural produce has to undergo a series of transfers or exchanges from one hand to another before it finally reaches the consumer.

Agricultural marketing is viewed as a process encompassing all the steps involved from the producers to the consumers including pre and post harvest operations. Such operation adds value to the produce in terms of time, place and farm utilities. Agricultural marketing has assumed increased importance after launching of new economic policy and consequent opening up of India's market to world market. There has been great concern in the recent years regarding the efficiency of marketing of agriculture produces in India.

It is believed that poor linkages in the marketing channels and poor marketing infrastructure are leading to high and fluctuating consumer prices, and to only a small proportion of the consumer rupee reaching the farmers. There is also substantial wastage, deterioration in quality, and frequent mis-match between demand and supply spatially and over time. 
The National Commission on Agriculture defined agricultural marketing as a process which starts with a decision to produce a saleable farm commodity and it involves all aspects of market structure of system, both functional and institutional, based on technical and economic considerations and includes pre and post- harvest operations, assembling, grading, storage, transportation and distribution. The Indian council of Agricultural Research defined involvement of three important functions, namely (a) assembling (concentration) (b) preparation for consumption (processing) and (c) distribution.

The term sustainable development means different things to different people. But, in essence, it is concerned with meeting the needs of people today without compromising the ability of future generations to meet their own needs.

\section{Importance and Objectives of Agriculture Marketing}

The farmer has realized the importance of adopting new techniques of production and is making efforts for more income and higher standards of living. As a consequence, the cropping pattern is no longer dictated by what he needs for his own personal consumption but what is responsive to the market in terms of prices received by him. While the trade is very organized the farmers are not Farmer is not conversant with the complexities of the marketing system which is becoming more and more complicated. The cultivator is handicapped by several disabilities as a seller. He sells his produce at an unfavorable place, time and price.

Agricultural marketing plays an important role not only in stimulating production and consumption, but in accelerating the pace of economic development. The agriculture marketing system plays a dual role in economic development in countries whose resources are primarily agricultural. Increasing demands for money with which to purchase other goods leads to increasing sensitivity to relative prices on the part of the producers, and specialization in the cultivation of those crops on which the returns are the greatest, subject to sociocultural, ecological and economic constraints. It is the marketing system that transmits the crucial price signals.

\section{The objectives of an efficient marketing system are:}

1. To enable the primary producers to get the best possible returns,

2. To provide facilities for lifting all produce, the farmers are willing, to sell at an incentive price,

3. To reduce the price difference between the primary producer and ultimate consumer, and

4. To make available all products of farm origin to consumers at reasonable price without impairing on the quality of the produce.

\section{Sustainable and agricultural marketing}

Sustainable agriculture is a phrase that has been around for decades; however, it has recently been receiving increased emphasis by businesses, organizations and political leaders. USDA's Ag Outlook Conference a couple months ago focused on sustainable agriculture, as did the Minnesota Agri-Growth Council annual meeting in October 2009. If you ask 100 people to define sustainable agriculture, you will likely get 100 different responses. Every person, business and organization seems to have its own definition of sustainability, as it relates to agriculture.

Twenty years ago, the 1990 Farm Bill defined sustainable agriculture as an integrated system of plant and animal production practices that is site-specific and will achieve the following:

- Satisfy human food and fiber needs.

- Enhance environmental quality and the natural resource base upon which the agriculture economy depends.

- Make the most efficient use of nonrenewable resources and on-farm resources, and integrate, when appropriate, natural biological cycles and controls.

- Sustain the economic viability of farm operations.

- Enhance the quality of life for farmers and society as a whole.

A more recent definition of sustainability is meeting the needs of the present, without compromising the ability of future generations to meet their own needs. That definition is quite complex and can have a widerange of interpretations. Most university experts and business leaders see sustainable agriculture as being sustainable environmentally, economically and socially. The environmental and economic aspects of sustainability have been around for decades, even centuries, in agriculture. The social aspect of sustainability is a newer concept that is gaining more and more focus in many developed countries in the world, including the U.S.

Many times, agricultural producers can agree on most of the economic and environmental aspects of sustainability, but struggle much more on the social aspects, due to the fact that many of the social aspects are not based on science and economic research, but rather on concepts, opinions, business strategies and personal preferences. Some social examples related to production agriculture include small farms vs. large farms, organic farms vs. traditional farms, range-fed beef vs. feedlot beet etc. Many of these farming and ranching practices 
have definition problems of their own. For example, naturally grown, which often used in promotion of food products, can have a lot of different meanings to producers and consumers.

The use of genetically modified (GMO) seed for crop production has been quite controversial in many foreign countries, as well as in some parts of the U.S., and with some organizations in the U.S. Many groups and individuals question whether or not GMO produced crops should be part of long-range agriculture sustainability. However, the primary benefit of using GMO seed is to control weeds and insects that damage crops, with less dependence on herbicides and insecticides that increase crop production costs, and potentially cause more threats to the environment and human health. The use of farm chemicals in the U.S. actually peaked in 1973, and has declined significantly in the past two decades. Producing food more economically, in a more environmentally friendly manner, would seem to meet a lot of definitions of agriculture sustainability.

As mentioned earlier, the concept of sustainable agriculture has existed for decades, and has been emphasized in farm bills as well as other federal and state legislation. Consider some of the agricultural facts and improvements from the past few decades that are related to economic, environmental and social achievements:

- Farmers today grow five times as much corn on $20 \%$ less land than they did in 1930.

- In 1940, one U.S. farmer produced enough food and fiber for 19 people, compared to production for 155 people today.

- From 1987 to 2007 , average corn productivity increased by over $40 \%$, and has increased at even more rapid pace in recent years.

- Corn producers grow $70 \%$ more corn/pound of fertilizer than they did in the 1970s.

- Reduced tillage and improved farm management practices have reduced soil erosion by about $43 \%$ in the last twenty years, while soil lost per bushel of corn produced has dropped by $69 \%$ during that same period of time.

- Carbon emissions per unit of output in crop production have dropped by one-third in the past 20 years, while energy used per unit of crop production has decreased by $60 \%$.

Emergence of new post-harvest technologies for sustainable agricultural products will need an improved data basis for important tree crops, mainly due to enhanced export potential. Intensive research on post-harvesting, grading, packaging and quality improvements of exporting materials is required. Moreover, export incentives training of personnel, financing, arranging fairs/publicity, etc. would help in maximizing export.

The concern of restructuring of agricultural market and mandi, adopting of modern agricultural management to ensure better prices to the farmers, marketing available agricultural commodities to the consumer and food processing industry at reasonable rates, creating basic infrastructure for development of modern marketing system, encouraging the growers to form associations/co-operative organizations for carrying out agricultural marketing activities and developing direct linkages with the wholesalers/retailers/processors/exporters need prompt attention of the individuals, groups and Governments.

The bottom line is that we need to produce a lot more food in the future to feed the world. The global population is expected to grow by over 2 billion people in the next 40 years, and it is estimated that we will have that we will have to double today's production levels to adequately feed the world population in 2050 . To meet these needs, it will become critically important for agricultural producers, businesses, organizations and political leaders in the U.S., and around the world, to reach consensus on what characterizes sustainable farming practices. As the social aspects of agriculture production gain increasing emphasis, we must be careful not to compromise the economic and environmental sustainability of agriculture, or our ability to provide a safe and adequate food supply.

The two institutions: co-operative marketing societies and regulated markets, together can assure, the presence of all these conditions. Accordingly if cooperative marketing societies are developed on the lines indicated above (along with regulated markets), the Indian agricultural marketing system can be considerably improved.

Especially in the current economic climate, food and beverage corporations need to assess all risks associated with their primary raw materials. This 45 -minute breakfast briefing is a chance for delegates to familiarize themselves with the key definitions associated with sustainable agricultural sourcing practices. Different agricultural regions, both nationally and globally, have specific challenges, whether its water, carbon or social. The objective of this session is to set the scene for the event, by defining the boundaries of the triple bottom line, in both national and global sourcing situations.

- Explaining what sustainable agricultural practice means for different food and beverage sectors and categories

- Characterizing the boundaries of the triple bottom line 
- Exploring the specific link between water and the agricultural supply chain -understanding why water is a critical sustainable sourcing driver

- Defining the key impacts and concerns upstream including carbon, fertilizers, soil fertility, land use, energy usage, farmer social impacts and food safety

- Examining the trade offs between sustainability and the availability of economically viable raw materials

\section{Causes for poor marketing of agricultural products in India}

Indian system of agricultural marketing suffers from a number of defects. As a consequence, the Indian farmer is deprived of a fair price for his produce. The main defects of the agricultural marketing system are discussed here.

1. Improper Warehouses: There is an absence of proper ware housing facilities in the villages. Therefore, the farmer is compelled to store his products in pits, mud-vessels; store houses etc. these unscientific methods of storing lead to considerable wastage. Approximately $1.5 \%$ of the produce gets rotten and becomes unfit for human consumption. Due to this reason supply in the village market increases substantially and the farmers are not able to get a fair price for their produce. The setting up of central warehousing corporation and state warehousing corporation has improved the situation to some extent.

2. Lack of grading and standardization: Different varieties of agricultural produce are not graded properly. The practice usually prevalent is the one known as "dara" sales wherein heap of all qualities of produce are sold in one common lot thus the farmer producing better qualities is not assured of a better price. Hence there is no incentive to use better seeds and produce better varieties.

3. Inadequate transport facilities: Transport facilities are highly inadequate in India. Only a small number of villages are joined by railways and Pucca roads to mandies. Produce has to be carried on slow moving transport vehicles like bullock carts. Obviously such means of transport cannot be used to carry produce to far-off places and the farmer has to dump his produce in nearby markets even if the price obtained in these markets is considerably low. This is even more true with perishable commodities.

4. Presence of large number of middlemen: The chain of middlemen in the agricultural marketing is so large that the share of farmers is reduced substantially. For instance, a study of D.D. Sidhan revealed, that farmers obtain only about $53 \%$ of the price of rice, $31 \%$ being the share of middle men (the remaining $16 \%$ being the marketing cost). In the case of vegetables and fruits the share was even less, $39 \%$ in the former case and $34 \%$ in the latter. The share of middle-men in the case of vegetables were $29.5 \%$ and in the case of fruits was $46.5 \%$. Some of the intermediaries in the agricultural marketing system are-village traders, Kutcha arhatiyas, Pucca arthatiyas, brokers, wholesalers, retailers, money lenders, etc.

5. Malpractices in unregulated markets: Even now the number of unregulated markets in the country is substantially large. Arhatiyas and brokers, taking advantage of the ignorance, and illiteracy of the farmers, use unfair means to cheat them. The farmers are required to pay pledging charge to the arhatiyas, weight charge for weighing the produce, "palledari" to unload the bullock - carts and for doing other miscellaneous types of allied works, "garda" for impurities in the produce, and a number of other undefined and unspecified charges. Another malpractice in the mandies relates to the use of wrong weights and measures in the regulated marks. Wrong weights continue to be used in some unregulated markets with the object of cheating the farmers.

6. Inadequate market information: It is often not possible for the farmers to obtain information on exact market prices in different markets. So, they accept, whatever price the traders offer to them. With a view to tackle this problem the government is using the radio and television media to broadcast market prices regularly. The newspapers also keep the farmers posted with the latest changes in prices, however the price quotations are sometimes not reliable and sometimes have a great time lag. The trader generally offers less than the price quoted by the government news media.

7. Inadequate credit facilities: Indian farmer, being poor, tries to sell off the produce immediately after the crop is harvested though prices at the time are very low. The safeguard of the farmer from such "forced sales" is to provide him credit so that he can wait for better times and better prices. Since such credit facilities are not available, the farmers are forced to take loans from moneylenders, while agreeing to pledge their produce to them at less than market prices. The cooperative marketing societies have generally catered to the needs of the large farmers and the small farmers are left at the mercy of the moneylenders.

8. Unfair practices by middlemen: The middlemen engaged in the distribution of agricultural produce adopt several unfair practices, such as manipulation of weights and measures, manipulation of prices, taking always a large quantity of the produce as samples etc.

9. Excessive marketing charges: The marketing charges required to be paid by the farmers for the marketing of their produce are excessive. They are required to pay heavy charges for loading, unloading, commission, etc.

10. Unorganized farmers and poor staying power of farmers: While the merchants who buy the agricultural produce are well organized, the farmers who sell the produce are not at all organized. As they are not organized, 
they do not have bargaining power in marketing their produce. They have to dispose of their produce at the prices offered by the dealers.

The farmers in India are generally, poor and heavily indebted. As such, they do not have staying power (i.e. they can not hold back their produce until they get better prices). They are forced to sell their produce immediately after harvest. As a result, they are not able to get fair prices for their produce.

Some of the other various causes that led to poor marketing of agricultural products in the country are as follows:

- Fluctuations in agriculture prices and supplies (surpluses/scarcities)

- Conflicting interests of farmers, middlemen and consumers

- Under utilization of resources such as rural godowns, market yards etc.

- Inadequate transportation, communication and information network.

- Imbalance in the spread of internal marketing network as well as in products

- Other factors such as distribution, seasonability, perishability, and enormity of production, storage, lack of processing make the problem of marketing more complex.

- Problem of plenty due to increased agricultural production leads to glut in the market and ultimately fall in price.

- Problem of scanty due to inadequate production, crop failure may finally result in rise in prices.

Among these problems, communication plays a vital role in determining the success or failure of commercialization! marketing of the agricultural produce in rural India. The extension system in the rural areas should be re-oriented to meet the challenges in $21^{\text {st }}$ century due to globalization. The following systemic approach will helps the extension officers to a greater extent in increasing the profits of small and marginal farmers in the rural India.

\section{Measures to Improving Agricultural Marketing}

As stated earlier, an efficient agricultural marketing system is essential for the successful development of agriculture. But the agricultural marketing system in India is defective in several respects. So, remedial measures have to be adopted for improving the agricultural marketing system in the country. In fact, of late, the government of India has adopted several measures to improve the agricultural marketing and to protect the farmers against the exploitation by middlemen.

.The various steps or measures undertaken by the government of India for the improvement of agricultural marketing in India are:

1. Marketing Surveys: In the first the Government has undertaken marketing surveys of various goods and has published these surveys. These surveys have brought out the various problems connected with the marketing of goods and have made suggestions for their removal.

2. Grading and standardization: The government has done much to grade and standardize many agricultural goods. Under the agricultural produce (Grading and Marketing) Act the Government has set up grading stations for commodities like ghee, flour, eggs etc. The graded goods are stamped with the seal of the Agricultural Marketing Department AGMARK. The "AGMARK" goods have a wider market and command better prices.

A Central Quality Control Laboratory has been set up at Nagpur and Eight other regional laboratories in different parts of the country with the purpose of testing the quality and quantity of agricultural products applying for the government's "AGMARK" have been created the Government is further streamlining quality control enforcement and inspection and improvement in grading.

3. Establishment of regulated markets: Regulated markets have been set up in all the important towns and cities of India for improving the agricultural marketing system. The number of regulated markets has increased considerably over the past 44 years. Their number has increased from 265 in 1950-51 to 4,452 on 31st March, 1980. By $31^{\text {st }}$ March, 1994, their number had risen to 6,809.

Regulated markets are markets set up by the State Governments in towns and cities for the efficient marketing of agricultural produce. The affairs of regulated markets are looked after by a market committee consisting of the representative of growers, traders, local bodies and the State Government.

The main functions of regulated markets are;

i. They ensure correct weights and measurement

ii. They standardize the market charges and prices

iii. They issue licenses to dealers in regulated markets and ensure that the rules and regulations of regulated markets are observed by the dealers.

iv. They also provide warehousing facilities for the produce of the farmers

v. They provide market information about the prevailing market prices of agricultural products. 
The regulated markets are of immense help in agricultural marketing. They help in the disposal of the products at fair prices. They help in the elimination of unhealthy market practices. They provide storage facilities for agricultural produce. They also provide market information about the prevailing prices.

4. Setting up of Co-operative Marketing Societies: The Government has encouraged the setting up of large number of co-operative marketing societies for the efficient marketing of agricultural produce. There has been much progress in this direction. A large number of co-operative marketing societies have been set up in the country. There are not only primary co-operative marketing societies, but also central marketing societies at the district level, state marketing federations at the state level and the National Agricultural Co-operative Marketing Federation at the all India level. Again there are separate state marketing federations for special commodities. Today, There are 6,000 primary marketing societies, of which 3,500 are special commodity marketing societies, 160 central marketing societies, 45 state marketing federations, (29 general purpose corporation and 16 special commodities marketing federations), 3 central marketing federations for special commodities and the National Agricultural Marketing Federation (NAFED).

The co-operative marketing societies have been of immense help to the farmers. They render the following services to farmers;

1. They help the farmers to market their produce at better prices and there by protect them against the exploitation by the middlemen.

2. They provide the necessary ware housing or storage facilities for the agricultural produce of the farmers.

3. They under take even the grading of agricultural produce.

4. They also undertake the processing of agricultural produce.

5. They provide credit facilities to the farmers

6. They even supply consumer goods to the farmers at fair prices.

5. Expansion of Ware housing facilities: The Government has done much expand the ware housing facilities for agricultural produce. The Central Government has set up the central ware housing corporation on $2^{\text {nd }}$ March, 1957 for the purpose of construction and maintenance of storage facilities at centers of all India importance for agricultural commodities. The various state Governments have established state warehousing corporations for the construction and maintenance of storage facilities at places where the central warehousing corporation has not provided such facilities. Besides the central and State warehousing corporations, the food corporation of India also has set up a large number of godowns throughout the country for the storage of buffer stocks of food grains. The government has also encouraged the co-operative marketing societies, regulated markets and even primary credit societies to set up godowns in many areas. Thanks to the efforts taken by the central and state governments, the ware housing and storage facilities in the country have increased considerably, and these storage facilities have enabled the farmers to keep their produce in the ware houses until they get better prices.

6. Extensions of Transport facilities to rural areas: The Government has also extended transport facilities connecting rural areas with the marketing centers. The extension of transport facilities to rural areas has helped the farmers to take their produce to distant markets and get better prices for their produce, and also helped them to reduce the cost of marketing their produce.

7. Provision of Market Information: The Government has made arrangements to provide market information about the prevailing or current pieces of agricultural crops through All India Radio and the Press. The market information about the prices of goods will be helpful to the farmers in selling their produce at the best prices.

8. State Trading in food grains: The Government has participated in trading in food grains. It is true that state trading in food grains is primarily intended for procurement of food grains for building up buffer stocks for distribution among deficit states. But it is also intended to help the farmers to get reasonable prices for their produce.

\section{Facilities Needed for Agricultural Marketing}

In order to have best advantage in marketing of his agricultural produce the farmer should enjoy certain basic facilities.

1. He should have proper facilities for storing his goods.

2. He should have holding capacity, in the sense, that he should be able to wait for times when he could get better prices for his produce and not dispose of his stocks immediately after the harvest when the prices are very low.

3. He should have adequate and cheap transport facilities which could enable him to take his surplus produce to the mandi rather than dispose it of in the village itself to the village money-lender-cummerchant at low prices.

4. He should have clear information regarding the market conditions as well as about the ruling prices, otherwise may be cheated. There should be organized and regulated markets where the farmer will not be cheated by the -dalals- and -arhatiyas-. 
5. The number of intermediaries should be as small as possible, so that the middlemens profits are reduced. This increases! The returns to the farmers.

\section{Action Taken Recently}

- NSAC signed onto a letter from Feeding America to Representatives in support of the Child Nutrition Reauthorization Bill.

- NSAC submitted Comments on the interim rule for the Rural Micro entrepreneur Assistance Program, July 27, 2010.

- In advance of the 2012 Farm Bill, NSAC hosted two producers to testify before the House Agriculture Subcommittees. Click here to view the testimony of Van Ayers before the Subcommittee on Rural Development, Biotechnology, Specialty Crops and Foreign Agriculture and click here to view the testimony of Margaret Smith before the Subcommittee on Horticulture and Organic Agriculture.

- NSAC launches Guide to USDA Funding for Local and Regional Food Systems work, April 2010.

- Letter from 41 organizations to House and Senate urging $\$ 50$ million in mandatory funding for Farm to School, May 3, 2010.

- Two-page summary of the $\$ 50$ million dollar ask for Farm-to-School from the Farm to School Collaborative (of which NSAC is a member).

- NSAC submits comments on the proposed rule for the Rural Micro entrepreneur Assistance Program, November 20, 2009.

- NSAC submits comments on the interim final rule for the Interstate Shipment of State-Inspected Meats, November 16, 2009.

- NSAC submits comments on the proposed "naturally-raised" meat label claim, November 13, 2009.

- Updated list of USDA State Rural Development Directors, October 27, 2009.

- NSAC recently submitted these Comments on Rural Development Guaranteed Loans Interim Rule.

\section{Sustainable Agricultural Export}

Agriculture, a core sector of the Indian economy, accounts for 30 per cent of the Country's GDP, 20 per cent of total export earnings, two thirds of country's workforce and livelihood for 70 per cent of the total population. The past accomplishments of this sector are a great strength to face the current problems and future challenges in the areas of greater efficiency (competitiveness), sustainability, poverty alleviation and continued food self sufficiency. With trade liberalisation, agricultural exports have also become an important national goal. The new economic regime, initiated since early nineties, has led to resetting of the goals of Indian agriculture towards global competitiveness and export orientation without compromising the basic premise of self-reliance. The emergence of the concept of sustainability of agricultural production has made the task more difficult for all those who are associated with agricultural production systems in the country. The present goals of Indian agriculture warrant reformation of strategies and action plans. Agricultural exports increased from about 600 million US dollars in 1960-61 to 3520 million US dollars in 1990- 91. During posteconomic reforms period, the value of agricultural exports has nearly doubled. The share of agri-exports in total exports, however, has remained more or less stable around 20 per cent, though the share of exports in agricultural GDP has been rising.

Commodities such as marine products, oil meals, rice, coffee, tea, spices, cashew, tobacco, castor oil, groundnut, sesame, fresh fruits, vegetables, pulses etc., are important export earners and are being exported to more than 110 countries. The encouraging results of goal-oriented Green Revolution, White Revolution, Yellow Revolution etc. enthuse the agricultural fraternity of the country to set a new goal for 'Agri-Export Revolution' which is not only the need of the hour but also a compulsion to strengthen and revitalize the economy of the country. While India holds an important position in the export market for a set of traditional agricultural commodities, new areas and new commodities are likely to emerge such as live animals and animal products, fruits, vegetables, floriculture, medicinal plants and processed agricultural products. In order to understand the emerging challenges and to identify ways and means of placing our country as a major player in the global export market for agricultural products, the National Academy of Agricultural Sciences (NAAS) in collaboration with the Rajasthan Agricultural University, Bikaner and the State Government of Rajasthan deliberated on the theme "Sustainable Agricultural Export" during the Fourth Agricultural Science Congress held at Jaipur in February, 1999. 


\section{Agricultural Exports - Advantage India}

Since independence, India has made rapid strides in agricultural production. Salient attainments include the following:

- Food production has increased from a mere 50 million tonnes in 1947 to over 199.30 million tonnes during 1996-97, and per capita net availability of food grains has grown from 395 gm per day in early 50s to 529gm in 1996-97.

- The country is now the largest producer of milk and the second largest producer of fruits and vegetables in the world.

- Oilseeds production has increased from 5.2 million tonnes in 1950 to 22.24 million tonnes in 1997.

- Fish and marine food production has risen from 7.5 to over 50 million tonnes, at present.

- Quality seed production which was negligible in 1947 has shown a quantum jump and is currently placed at 7 million quintals. A large number of private seed companies have also come up.

- Both the irrigated and the potentially irrigated areas have increased since Independence. Efficient methods like sprinkler and drip irrigation have become popular in arid and semi-arid areas.

- The total fertilizer consumption has gone up and India now ranks fourth in the world, although the per unit area consumption is still low.

- India is also the largest reservoir of trained manpower in the world.

- Despite agriculture sector being not-taxed, prices of several agricultural commodities are below international prices, thus conferring trade advantages. Despite impressive strides that the country has made in agricultural production, India has not yet become a major player in the international arena as far as exports are concerned.

The broad export strategy for Indian agriculture would, therefore, be to strengthen and widen the export market for established 'commercial commodities' like tea, coffee, spices, cotton, jute, sugar, oil meals etc., and also to create and capture new export market for 'dynamic commodities' like meat, dairy products, poultry, fishery products, vegetables, fruits, floriculture etc., whose demand in the international market is buoyant. India has a comparative advantage in many of these commodities due to availability of varied agro climatic conditions, diversified commodity mix and low wage rates leading to lower cost of production etc. The major plank of our foreign trade strategy must be on finding a niche for exports of the above mentioned nonconventional and dynamic commodities. This has to be achieved in the context of stricter control processes under Sanitary and Phytosanitary (SPS) Agreement and other non-tariff barriers viz., Technical Barriers to Trade (TBT), etc.

\section{Conclusion}

A good marketing system is one, where the farmer is assured of a fair price for his produce and this can happen only when the following conditions are obtained, the number of intermediaries between the farmer and the consumer should be small; the farmer has proper storing facilities so that he is not compelled to indulge in distress sales, efficient transport facilities are available, the malpractices of middlemen are regulated, fanners are freed from the clutches of village moneylenders and regular market information is provided to the farmer.

The central and state governments have taken up a number of measures for improving the agricultural marketing in the country. Thanks to the various measures undertaken by the government, agricultural marketing has improved considerably in recent years. But still, a great deal remains to be done in agricultural marketing, especially in the fields of grading, expansion of warehousing facilities and extension of transport facilities to rural areas.

Agriculture continues to play a pivotal role in most Asian countries. Its contribution to their gross domestic product is substantial, its share in employment is high; and a large part of exports is accounted for by agricultural commodities. In the family budget of the majority of households, food and agricultural products account for the largest share. With greater focus on sustainable development, agriculture has acquired a new significance. Sustainable use of land and water, application of pesticides and fertilizers, the place of animals, prospects for afforestation, and issues of biodiversity are considered vital. As should be expected, the records of Asian countries vary in these respects. Yet there are several common features and emerging trends in agricultural development in the region which have a bearing on its march towards sustainable development.

\section{Bibliography}

[1]. Anirbau Biswas (2004). “Agricultural Marketing in India”, $13^{\text {th }}$ July 2004, pp. 1-4.

[2]. Raman, B.S. (1998). "Elements of Indian Economy", United Publishers, Jeppu, Managalore- 575001, pp. 129-134.

[3]. Carter, S. (1997). "Global agricultural marketing management (marketing and agribusiness texts-3)", Food and Agriculture Organization of the United Nations (FAG), Rome, Italy.

[4]. Kotler, P., Arunstrong, G., Somuders, J. and Wong, V. (2002). "Principle of marketing", $3^{\text {rd }}$ European edition, Practice Hall, Upper Saddle River, NJ, USA, p. 56. 